\title{
Chronological Narrative and Locale-based Narrative in Early Chinese Prose: A Case Study of Wu-Yue Rivalry in Zuozhuan and Guoyu
}

\author{
Jia LI \\ National Institute of Education, Nanyang Technological University \\ Asian Languages \& Cultures, Singapore
}

Received: 06-05-2016

Accepted: 18-06-2016

Published: 01-07-2016

doi:10.7575/aiac.ijclts.v.4n.3p.44

URL: http://dx.doi.org/10.7575/aiac.ijclts.v.4n.3p.44

\begin{abstract}
Chinese narrative tradition traces back to the Pre-Qin Period, and very often, such early historical prose employs a distinct narrative style. Amongst them, Zuozhuan is representative of the "chronological narrative" style, and Guoyu is representative of the "locale-based narrative" style. This paper seeks to analyse the narrative of "Wu-Yue rivalry" in the two texts from a narratology point of view, to understand how the two narrative styles influenced the plot development, characterisation, narrator perspective and significance, and narrative characteristics.
\end{abstract}

Keywords: Chronological Narrative; Locale-based Narrative; Zuozhuan; Guoyu; Wu-Yue Rivalry

\section{Introduction}

Chinese narrative tradition had a long history that could be traced back to Pre-Qin China, and many of these early biographic literature employed a distinct narrative style. American metahistorian, Hayden White, described "the explanation effects of historical events arise from the coherence in an order of events, and this coherence was the realisation of a continuous plot" (White 354). Therefore, a historian's understanding of an incident's purpose and desired effects was largely dependent on how the event was rendered by the compiler. In Pre-Qin China, the same events were presented in ways that varied according to the text's author. Guoyu 国语 was the first text that presented the history of different states as individual chapters. Generally, a compilation of anecdotes, it had sections that serve narrative purposes. For example, Jinyu 晋语, Wuyu 吴语, Yueyu 越语, were independent chapters made up of different sections, with some form of continuity existing among the sections, presenting a coherent history of each state. In contrast, Zuozhuan 左传 was a densely written history text that details events in chronological order, its narratives expound complex and important historical events and characters. Being written in the style of Chunqiu 春秋 "with events tied to days, days to months, months to seasons, and seasons to years", it presented historical events in a linear logic of succession (Ruan 1703). Professor Lee Long-shien in his comparison of Zuozhuan and Guoyu, pointed out that "Chunqiu and Zuozhuan set the precedent for annalistic style, chronicling historical events by 'time' in 'chronological narrative'; while Guoyu chronicles history by 'space' in 'locale-based narrative"” (Lee). With that, this paper shall through close analysis of “Wu-Yue rivalry 吴越相争”, study how different narrative styles led to the creation of Zuozhuan and Guoyu's unique characteristics. As the narrative of Wu-Yue rivalry is more organised in Guoyu and fairly disjointed in Zuozhuan - spread over ten years - this paper shall begin by organising Zuozhuan's account of this rivalry.

\section{Narrative of Wu-Yue Rivalry in Zuozhuan}

\subsection{Remotes Causes of Wu-Yue Rivalry}

Battles between the States of $\mathrm{Wu}$ and Yue took place in the $5^{\text {th }}$ and $24^{\text {th }}$ year of Duke Zhao of Lu's reign and in the $5^{\text {th }}$ year of Duke Ding of Lu's reign, over a period of more than 30 years. ${ }^{1}$

$\mathrm{Wu}$ and Yue were neighbouring states along the South-eastern coast, and disputes were inevitable as they grew stronger in strength. Their rivalry was set in place during the war between the States of $\mathrm{Wu}$ and $\mathrm{Chu}$ that took place in the $5^{\text {th }}$ year of Duke Zhao of Lu's reign (537 BC):

In winter, in the $10^{\text {th }}$ month, the viscount of Chu, along with several princes and [the chiefs of] the eastern $\mathrm{Yi}$, invaded $\mathrm{Wu}$, in retaliation for that State's taking Jin, Le, and Ma. Weishe joined him with the army of Fanyang at Xianei. Chang Shouguo, a great officer of Yue, joined him with a force at Suo (Yang 1270; Legge 606).

冬十月, 楚子以诸侯及东夷伐吴，以报棘，栎，麻之役，薳射以繁扬之师会于夏汭，越大 夫常寿过帅师会楚子于琐. ${ }^{2}$ 。

Yue became a member of the Chu-commandeered coalition forces in its expedition against $\mathrm{Wu}$. Thereafter, in the $24^{\text {th }}$ year of Duke Zhao's reign (518 BC), Yue joined King Ping of Chu 楚平王 in its expedition against Wu again, with its dafu 大夫 and gongzi 公子 donating supplies and boats respectively in support.

The viscount of Chu fitted with a naval expedition to reach the borders of Wu. Shenyin Xu said, "In this expedition, $\mathrm{Chu}$ is going to lose a city. Instead of soothing the people, we are toiling them. While $\mathrm{Wu}$ is being quiet, we are 
stimulating it to move. If Chu follow in our footsteps, as preparations have not been made on our borders, is it possible we should not lose [one or more] cities?" Xu An, a dafu of Yue, met the king with complimentary offerings at the bend of Yuzhang, and the gongzi Cang of that State sent him a ship, following him also with a force, along with Shoumeng. When he had got to Yuyang, the king returned. The men of Chu then followed; and as the people on the borders were not prepared for them, they extinguished Chao and Chongli and returned (Yang 1270; Legge 703).

楚子为舟师以略吴疆, 沈尹戌曰: “此行也, 楚必亡邑。不抚民而劳之, 吴不动而速之, 吴踵楚, 而疆埸无备 ，邑能无亡乎? ”越大夫胥犴劳王于豫章之汭，越公子仓归王乘舟。仓及寿梦帅师从王，王及囯阳而还。吴人 踵楚, 而边人不备, 遂灭巢及钟离而还。

As an appendage of Chu - a large southern state - Yue fought under the might of Chu and was able to launch sneak attacks on $\mathrm{Wu}$ on numerous occasions. This was the remote historical cause of the Wu-Yue rivalry that led to King Helu of Wu's 吴王圔闾 invasion of Yue eight years later.

The two States only engaged in direct fire in the $32^{\text {nd }}$ year of Duke of Zhao's reign (510 BC), King Helu invaded neighbouring Yue in revenge for its previous intrusion.

In summer, Wu moved against Yue, this was the first instance of a [regular] expedition on the part of Wu against Yue (Yang 1516; Legge 740).

夏, 吴伐越。始用师于越也。

In the $5^{\text {th }}$ year of Duke Ding of Lu's reign $(505 \mathrm{BC}), \mathrm{Wu}$ and Yue had another confrontation when Wu invaded Chu, and Yue took advantage of the occasion to attack $\mathrm{Wu}$.

Yue entered the boundaries of $\mathrm{Wu}$, as the viscount of Wu was in Chu with all his forces (Yang 1550; Legge 759).

$$
\text { 越入吴, 吴在楚也。 }
$$

Wu was often victorious in its battles with $\mathrm{Chu}$, but it was forced into a crisis on both ends when Yue waited in the rear and invaded it from time to time. Being attacked and fighting on two ends was one of the causes of Wu's eventual defeat.

\subsection{Battles Between Wu and Yue}

Conflicts of interest between $\mathrm{Wu}$ and Yue were increasingly acute and sensing its seriousness, King Helu intended to solve this once and for all. This led to the Battle of Zuili 欈李之战 between Wu and Yue in the $14^{\text {th }}$ year of Duke Ding's reign (496 BC), ushering in the era of Wu-Yue rivalry. Zuozhuan's narrative of this battle was relatively brief: Yue defeated $\mathrm{Wu}$ by scaring the soldiers before battle with criminals committing suicide by cutting their throat, right on the front line. King Helu was mortally wounded in battle; and the two states forged hatred. King Fuchai of Wu 吴王夫差 , son of King Helu of $\mathrm{Wu}$, then assumed the throne. With such hatred in mind, he swore to take revenge. Zuozhuan continued with a pre-narrative of "three years later, he took revenge on Yue", foretelling King Fuchai's successful revenge three years later. This pre-narrative shaped "King Fuchai's revenge" as a self-contained story within the wider context of the $\mathrm{Wu}-Y u e$ rivalry, enhancing the fullness of the plot.

A second war broke out between the two states in the $1^{\text {st }}$ year of Duke Ai of Lu (494), this Battle of Fujiao 夫椒之战 almost ended Yue, but Zuozhuan's narrative of this was unusually brief:

King Fuchai of Wu, defeated Yue at Fujiao, in return for the Battle of Zuili, and then went on to enter [the capital of] that State (Yang 1605; Legge 794).

吴王夫差败越于夫椒, 报欈李也, 遂入越。

"In return for the Battle of Zuili" was a narrative intervention by the author from his omniscient narrative perspective, its purpose was to highlight this battle as a revenge for the defeat suffered by Wu in the $14^{\text {th }}$ year of Duke Ding's reign. The author's commentary formed a continuity with previous events, enhancing the coherence of this series of events.

The third Wu-Yue war broke out in the $13^{\text {th }}$ year of Duke Ai of Lu (482 BC). King Goujian of Yue 越王勾践 assaulted Wu when King Fuchai of $\mathrm{Wu}$ was leading an expedition to the north, dealing him a heavy a blow. In the $17^{\text {th }}$ year of Duke Ai's reign (478 BC), the two states had their fourth confrontation where Yue was victorious in its attack on Wu. Thereafter, in the $20^{\text {th }}$ year of Duke Ai's reign $(475 \mathrm{BC})$, the troops of Yue surrounded Wu, and King Fuchai of Wu committed suicide two years later in the $22^{\text {nd }}$ year of Duke Ai's reign $(473 \mathrm{BC})$ :

In winter, in the $11^{\text {th }}$ month on Dingmao, Yue extinguished $\mathrm{Wu}$, and proposed to the king of it to reside in Yongdong. He declined, saying, "I am old; how can I serve your lordship?" And with this he strangled himself. They carried his body back to Yue (Yang 1719; Legge 851).

冬十一月丁卯, 越灭吴, 请使吴王居甬东。辞曰: “孤老矣, 焉能事君? ”乃缢。越人以归

\section{Comparison of Plot in Guoyu and Zuozhuan}

Details of the Wu-Yue rivalry varies considerably in both texts, hence this section endeavours to provide a comparison in the area of narrative time, plot angles etc.

\subsection{Narrative Time and Narrated Time}

Narrative time refers to the actual time the plot takes place in real life. In Wuyu, the narrative of King Fuchai's battles against the States of Yue, Qi, Jin etc., and its eventual defeat, began in the 1st year of Duke Ai's reign (494 BC) and 
ended in the $22^{\text {nd }}$ year of Duke Ai's reign $(473 \mathrm{BC})$ with King Fuchai's suicide. A total narrative time of 22 years depicting historical events of Wu. In Yueyu - divided into two volumes - the narrative of King Goujian's revenge commenced in the $14^{\text {th }}$ year of Duke Ding's reign (496 BC) and ended in the $22^{\text {nd }}$ year of Duke Ai's reign as well, totalling 24 years, which was similar to Wuyu. In contrast, Zuozhuan's depiction of the Wu-Yue rivalry began in the $5^{\text {th }}$ year of Duke Zhao's reign with Yue joining Chu in its expedition against Wu. Its detailed description of the rivalry between the two states ended in the $22^{\text {nd }}$ year of Duke Ai's reign, with Yue conquering $\mathrm{Wu}$, and King Fuchai of Wu committing suicide, totalling 64 years.

Narrated time refers to the time span of the plot which was presented in the text. Between Guoyu and Zuozhuan, the former often utilised the difference between narrated time and narrative time to highlight important events. In Guoyu's narrative of the Battle of Fujiao - Yue lost to $\mathrm{Wu}$ - and the Battle of Ailing 艾陵之战 - between Wu and Qi - Wuyu employed the narrative technique of time shorting, where the narrated time was shorter than the narrative time. For instance, its narrative of a war was covered in just a one sentence: "King Fuchai of Wu led an expedition against Yue, and King Goujian of Yue fought back with his forces" and "in the $12^{\text {th }}$ year, it went on an expedition against Qi, they battled at Ailing and defeated the Qi”. In its narration of the Battle of Huangchi 黄池争盟, the technique of time stretching was employed to slow the development of events, to magnify the strength of the Wu troops during the meet. Time coverage was used for the account of King Goujian of Yue asking for the advice of the assembled generals, before its expedition against $\mathrm{Wu}$. This technique of time coverage, where narrative time equates to narrated time, reproduces a true to life historical scene and plot.

Zuozhuan employs the time shorting in its narrative as well, for example, it merely described the war in which Yue conquered $\mathrm{Wu}$ in the $22^{\text {nd }}$ year of Duke Ai's reign as "Yue extinguished Wu". Zuozhuan typically expounds on on important wars, but its narrative of the wars between $\mathrm{Wu}$ and Yue were quite different - briefly describing wars in a single sentence. These wars include: Wu's expedition again Yue in the $32^{\text {nd }}$ year of Duke Zhao's reign; Yue's invasion of Wu in the $5^{\text {th }}$ year of Duke Ding's reign; the Battle of Zuili in the $14^{\text {th }}$ year of Duke Ding's reign; the Battle of Fujiao in the $1^{\text {st }}$ year of Duke Ai's reign; Yue's expedition against $\mathrm{Wu}$ in the $13^{\text {th }}$ and $17^{\text {th }}$ year of Duke Ai's reign; Yue besieging $\mathrm{Wu}$ in the $20^{\text {th }}$ year of Duke Ai's reign; and Yue conquering Wu in the $22^{\text {nd }}$ year of Duke Ai's reign. This brief narration of important events might be due to the lack of historical materials, but it was more likely due to the reasons put forth by Liu Shipei: "the reasons for its rise and fall has been accounted for in earlier narratives, nothing needs to be added" (Wu 1139). The reasons for Wu's meteoric rise and fall under King Fuchai's leadership has been recounted in earlier narratives, it is unnecessary to further relate the foreseeable outcome here.

\subsection{Comparison of Plot}

While Zuozhuan provided a linear account of the Wu-Yue rivalry, it also chronicled the relationship of Wu, and Yue, with other States, with special focus on the relationship of Wu-Chu; Wu-Qi; Wu-Lu; and Wu-Jin. However, these were not included in Guoyu. This section would compare the two texts' narratives of the Battle of Fujiao, the Meeting of Huangchi, Yue conquering Wu and the suicide of King Fuchai etc.

\subsubsection{The Battle of Fujiao and the Empty Alliance}

Battle of Fujiao broke out in the $1^{\text {st }}$ year of Duke Ai's reign, this war almost destroyed Yue, but Zuozhuan and Guoyu's narrative of this was unusually brief:

King Fuchai of Wu, defeated Yue at Fujiao, in return for the Battle of Zuili, and then went on to enter [the capital of] that State (Yang 1605; Legge 794).

吴王夫差败越于夫椒，报欈李也，遂入越。(《左传》)

King Fuchai of Wu led an expedition against Yue, and King Goujian of Yue fought back with his forces $(\mathrm{Xu} 536)$.

吴王夫差起师伐越, 越王句践起师逆之。（〈吴语〉）

Clearly, this Battle was not the centre of narrative, but more of an introduction that brought attention onto Wu Zixu's 伍子胥 evaluation of the current situation and his advice to King Fuchai of Wu. This narrative focus on their dialogue served to promote the development of the plot.

Following King Fuchai's rejection of Wu Zixu's advice, Zuozhuan's author inserted a pre-narrative by detailing Wu Zixu's prediction:

Give Yue ten years for the growth of its people and the collection of its resources, and [other] 10 years for the instruction of its people, and in little more than 20 years, [the capital of] Wu is likely

to be made a pool (Yang 1607; Legge 794)?

越十年生聚，而十年教训，二十年之外，吴其为沼乎?

The author utilised Wu Zixu's prediction of Wu's eventual fall to pre-narrate future incidents, allowing readers to link up a series of disjointed events, establishing a comprehensible storyline that might be lacking in Zuozhuan's chronological narrative. This was a successful foreshadow on the author's part as exactly 20 years after Wuyuan's prediction, in the $22^{\text {nd }}$ year of Duke Ai's reign, Yue conquered Wu.

Yueyu xia 越语下 narrated the same event in a different manner, presenting it in a form of repeated dialogue between King Goujian of Yue and Fan Li 范蟲. Initially, King Goujian did not heed Fan Li's advice and insisted on attacking $\mathrm{Wu}$, which almost caused the fall of Wu. King Goujian then realised his mistake and began to humbly ask Fan Li for advice. 
3.2.2 The Meeting of Huangchi

Both Zuozhuan and Guoyu's narration of the meeting of Huangchi 黄池之会 took into account the development of events in both the States of Wu and Yue. One works on its account of Wu and Jin meeting at Huangchi; while the other focuses on Yue's surprise assault on $\mathrm{Wu}$ when $\mathrm{Wu}$ was at the meeting of Huangchi, capturing its crown price and troops guarding the city.

However, there was a significant difference between the two: Wuyu's locale-based narrative style meant its narration was not restricted by chronology, and provided it the flexibility to recount a related and important event (the construction of Hangou) in the same story:

After killing Shenxu, King Fuchai of Wu led an expedition to the north, before crops could be harvested. People were mobilised to construct the Hangou that engages the States of Song and Lu, with the north reaching River Yi and the west reaching River Ji. [King Fuchai of $\mathrm{Wu}$ ] travelled on this canal for the meeting with the Duke Ding of Jin at Huangchi (Xu 545).

吴王夫差既杀申胥，不稔于岁，乃起师北征。阙为深沟，通于商、鲁之闲，北属之沂，西 属之济, 以会晋公午于黄池。

In addition, Wuyu in its narration of King Fuchai heeding Wang Sunluo's 王孙倠 advice on gaining the status of hegemon at the meeting of Huangchi before returning to $\mathrm{Wu}$, utilised dialogues of characters to promote development of the plot. At the same time, the author employed scene description to provide a dynamic sketch of King Fuchai's troops when he was at the meeting of Huangchi:

At dusk, King Fuchai of Wu commanded his troops to have a good meal and for the horses to be well-fed. In the middle of the night, they were ordered to have their weapons on hand, armour on, horses leashed, fire extinguished in the stove, and into formation. With every hundred soldiers in a row, and with every hundred rows they form a phalanx. The first soldier in every row holds a bell in one hand, and a spear in the other; beside him there is a flag and a shield made from rhinoceros' skin. Every ten rows are commanded by an official who has a flag and a drum, with a book of war under his arm and a drumstick in his hand. Every ten flags form a phalanx led by a general who has a sun-moon flag and a drum, with a book of war under his arm and a drumstick in his hand. This formation of ten thousand soldiers wore white robes, held white flags with dragon imprint, spotted white armour, carried arrows with white fletch, and looked like a sea of white imperata when seen from afar. King Fuchai of Wu stood before the formation with an axe in hand and a white flag with bear and tiger imprint beside him. The formation of ten thousand soldiers on the left wore red robes, held red flags with a falcon imprint, spotted red armour, carried arrows with red fletch, and looked like a sea of fire. The formation of ten thousand soldiers on the right wore black robes, held black flags, spotted black armour, carried arrows with black fletch, and looked like a sea of black ink. This formation of thirty thousand armour-clad soldiers made offensive gestures, and were already in formation when the rooster crowed. They were only one $l i$ away from the Jin troops. Before dawn, King Fuchai of Wu held up his drumstick, struck the drum and bell. The troops echoed by ringing bells and playing passionate music, the soldiers roared forward and their battle cry was earth-shattering (Xu 546).

吴王昏乃戒, 令秝马食士。夜中, 乃令服兵擐甲, 系马舌, 出火灶, 陈王卒, 百人以为彻 行, 百行。行头皆官师, 拥铎拱稽, 建肥胡, 奉文犀之渠。十行一嬖大夫, 建嫙提鼓, 挟 经秉枹。十旌一将军, 载常建鼓, 挟经秉枹。万人以为方阵, 皆白常、白旗、素甲、白羽 之矰, 望之如茶。王亲秉钱, 载白旗以中陈而立。左军亦如之, 皆赤裳、赤旗、丹甲、朱 羽之矰, 望之如火。右军亦如之, 皆玄常、玄旗、黑甲、乌羽之矰, 望之如墨。为带甲三 万，以势攻，鸡鸣乃定。既陈，去晋军一里。昧明，王乃秉枹，亲就鸣钟鼓、丁宁、錞于 , 振铎, 勇怯尽应, 三军皆哗扣以振旅, 其声动天地。

3.2.3 Yue's Conquest of $\mathrm{Wu}$ and the Suicide of King Fuchai of Wu

The State of Wu was Zuozhuan's main narrative for this series of events. It began with Yue attacking and defeating Wu once again in $17^{\text {th }}$ year of Duke Ai's reign. Thereafter, gongzi Qing persuaded King Fuchai of Wu repeatedly to learn from his mistakes, but all these fell on deaf ears. By the November of $20^{\text {th }}$ year of Duke Ai's reign, Wu was entirely besieged by Yue's troops; and in 474 BC, Yue sent messengers to Lu in a show of strength. The following year, $473 \mathrm{BC}$, King Fuchai of $\mathrm{Wu}-$ an overlord of its generation - committed suicide.

On the other hand, in Guoyu's Wuyu, King Goujian of Yue was the main narrative for this series of events. It developed the plot via dialogues between King Goujian and Wen Zhong, Shen Baoxu, and other dafus, respectively; and also via his orders to his wives, dafus, and troops. Dialogues were also utilised to express attitudes and positions of the two protagonists of the event. Before his death, King Fuchai of Wu said:

If the dead have no consciousness, so be it; if the dead do have consciousness, then how am I going to face the loyal official Wuyuan (Xu 562)!

使死者无知，则已矣，若其有知，君何面目以见员也！ 
This echoed Shenxu's 申胥 suicide earlier on:

The dying Shenxu said, "Cut off my head and hang it over the capital's East Gate, I want to witness Yue's invasion and the collapse of Wu with my own eyes." The enraged King Fuchai of Wu said, "I will not allow your great officer to witness anything." Wuyuan's body was then ordered to be wrapped in a leather bag and thrown into the Yangtze River (Xu 545).

(申胥) 将死, 曰: “以悬吾目于东门, 以见越之入, 吴国之亡也。”王愠曰: “孤不使大夫 得有见也。”乃使取申胥之户，盛以鸱夷，而投之于江。

This way of writing ensured fullness and coherence in the series of events. At the end, Wuyu's author through its omniscient narrative perspective, did a narrative intervention to highlight his opinions on this incident:

After wiping out $\mathrm{Wu}$, King Goujian of Yue pushed his troops northward to attack the other states. The rulers of these states knew they were no match and hence, the states of Song, Zheng, Lu, Wei, Chen, Cai etc., brought their symbols of jade and submitted to the rule of King Goujian. King Goujian was able to succeed as he treated his officials with respect and was willing to listen and accept their ideas (Xu 562).

越灭吴, 上征上国, 宋、郑、鲁、卫、陈、蔡执玉之君皆入朝。夫唯能下其群臣, 以集其 谋故也。

King Goujian of Yue was the central figure in Yueyu shang's 越语上 narrative of this series of events. The plot was based on a series of speeches: King Goujian's dialogue with dafu Zhong; Wu Zixu's advice to King Goujian; and the King's lecturing of his troops. These speeches and a series of policy changes led the development of the plot. Hence, when King Goujian of Yue decided on leading an expedition against $\mathrm{Wu}$,

The people encouraged one another - fathers encouraged sons; elder brothers encouraged younger brothers; wives encouraged husbands - extoling that, "Where can we find such a wise leader, and how can we not serve him wholeheartedly?" Therefore, Yue was able to beat Wu in the battles at You, then at Mo, and again at Jiao (Xu 572).

国人皆劝, 父勉其子, 兄勉其弟, 妇勉其夫, 曰: “孰是君也, 而可无死乎? ”是故败吴于 直，又败之于没，又郊败之。

It was no surprise that $\mathrm{Wu}$ was eventually annexed by Yue.

As for Yueyu xia, the focus was on a series of dialogues between King Goujian of Yue and Fan Li, revealing the increasing divergence of political and military strength between $\mathrm{Wu}$ and Yue, which in turn worked to narrate the process of Wu falling into Yue's hands:

[On the] fourth year [of his return from Wu], King Goujian summoned Fan Li and asked... He replied... King Goujian said, "Yes. (Xu 579-580)"

四年，王召范蛍而问焉 ......对曰.....王曰: “诺。”

In another year, King Goujian summoned Fan Li and asked... He replied... King Goujian said, "Yes. (Xu 580-581)"

又一年，王召范蟲而问焉......对曰......王曰: “诺。”

In another year, King Goujian summoned Fan Li and asked... He replied... King Goujian said, "Yes. (Xu 581-582)"

又一年, 王召范蟲而问焉......对曰......王曰: “诺。”

In another year, King Goujian summoned Fan Li and asked... He replied... The enraged King Goujian said... Fan Li replied... (Xu 582-583)

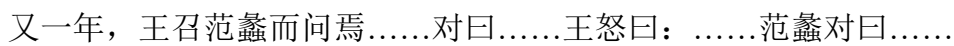

Until September, King Goujian summoned Fan Li and asked... He replied... King Goujian said, "Yes." The troops were then mobilised for the attack on Wu and were stationed around the Five Lakes. Wu got news of Yue's attack and sent troops who were high in morale to challenge the attackers, five times in a day. King Goujian could not contain his anger and wanted to engage the enemy. But Fan Li advised the King... King Goujian said, "Yes." Hence, they did not go engage the enemy. Fan Li said... King Goujian said, "Yes." Hence, they did not engage Wu (Xu 583-586).

至于玄月, 王召范蟇而问焉 ......对曰 .....王曰: “诺。”遂兴师伐吴, 至于五湖。吴人闻之 , 出而挑战, 一日五反。王弗忍, 欲许之。范蟲进谏曰: .....王曰: “诺。”弗许。范蟲曰 : …..王曰: “诺。”弗与战。

[King Goujian's] troops surrounded Wu for three years, and they were defeated without war. King Fuchai of Wu brought his closest officials and treasures of Wu to Gusu Tai to avoid the Yue troops (Xu 586).

居军三年，吴师自溃。吴王帅其贤良与其重禄以上姑苏。 


\subsubsection{Plots Missing from Wuyu and Yueyu}

Zuozhuan provided a chronological narrative of the important happenings between Wu and other countries, while Wuyu and Yueyu had the region of Wu and Yue at its core and its narration focused on the events surrounding King Fuchai of $\mathrm{Wu}$ after his loss at the Battle of Fujiao, which included how he reformed the country with the aid of his advisors and eventually defeating Wu. Therefore, this differing focus meant that unlike Zuozhuan, Wuyu and Yueyu did not include many important events in its narration, which were crucial in having a comprehensive understanding of why Wu failed while Yue succeeded. Zuozhuan often utilised prophecies by characters to pre-narrate events. For instance, it was written in the $4^{\text {th }}$ year of Duke Ding's reign: "From the date of King Zhao's accession, there was no year in which Chu was not [somehow] attacked by Wu", showing that both parties had paid a huge price after years of war. In the $1^{\text {st }}$ year of Duke Ai's reign, the author of Zuozhuan used the words of the State of Chen to prophesise that, following years of war and ill treatment of its people, Wu was not far from its demise:

I have heard that States flourish when they regard their people as if apprehensive of their receiving hurt, that brings prosperity. States again perish when they treat their people as earth or grass, that brings calamity. Although Chu does not show [much] kinds, it does not slay its people, whereas $\mathrm{Wu}$ is daily ruined with fighting, and the bones of its people lie like weeds in the ground. They experience no kindness from it. Heaven perhaps is teaching Chu good lessons; but what [future] time need we look to for calamity to visit Wu (Yang 1607-1608; Legge 795)?

臣闻国之兴也，视民如伤，是其福也。其亡也，以民为土芥，是其祸也。楚虽无德，亦不 艾杀其民，吴日敉于兵，暴骨如莽，而未见德焉。天其或者正训楚也！祸之适吴，其何日 之有?

Following which, it borrowed Chu's Prime Minister Zixi’s 令尹子西 words to prophesise “such as one will first defeat himself; how can he defeat us?" Then in the $7^{\text {th }}$ years of Duke Ai's reign, Wu demanded a hundred buffaloes from Lu, and Zifu Jingbo 子服景伯 said, “Wu will go to ruin, casting away [the rule of] heaven and going against [the example of] its own ancestral House". While Zigong 子贡 and Ji Kangzi 季康子 was more direct in their statements, “it was considered that $\mathrm{Wu}$ could do nothing [great]."

In addition, Zuozhuan's narrative revealed that King Fuchai forced his views on people and neither respect lifa 礼法 nor wende 文德. For example, Wu's failed alliance with Yue; Wu's reluctance in retreating even after its defeat by Yue; Wu demanding a hundred buffaloes from the Lu; the States of Lu, Wei, and Song, leaving the alliance; only the State of Jin sent messengers after Wu was besieged. The author then pointed out Wu's eventual demise by using Zigong's statement: "We are afraid of your great State. It is laying its commands upon the States without regard to the rules of propriety, and how can we measure to what that course will go”. He further pushed his point with Yanling Jizi's 延陵季子 words: "(Our two rulers) do not endeavour to display virtue, but are striving by force for the supremacy of the States. Of what offence have the people been guilty?" These completed the narrative of the Wu-Yue rivalry, and essentially, enhanced coherence and fullness of the plot for easier understanding.

\subsection{Characterisation of King Fuchai of Wu}

The choice of narrative style - whether chronological style of locale-based style - determined the focus of the plot and narrative, which had a direct impact on characterisation and the author's perspective and purpose. In the narrative of Wu-Yue rivalry, King Fuchai of Wu was no doubt a failed monarch, while King Goujian of Yue was the winner who had the last laugh. However, due to the different narrative styles employed, there were big differences in the characterisation of both Kings in Zuozhuan and Guoyu.

Wuyu and Yueyu's narrative had a regional focus, mostly detailing King Goujian's conquest of Wu. In these texts, King Fuchai of Wu was fashioned as wilful, arrogant, extravagant, overconfident, forming a huge contrast with King Goujian's humble and polite character. In addition, the overambitious and unrealistic King Fuchai was also designed to contrast with the calm and far-sighted Wu Zixu. These two comparisons were intended to emphasis King Fuchai as an arrogant, haughty, fatuous, and self-indulgent ruler.

In contrast, Zuozhuan chronicled history in order of years, hence its narration of events was not restricted by space and time, allowing it to develop a more robust character image. In addition, due to the historical relationship between Wu Taibo 吴太伯 and the Zhou royalty, the author sees King Fuchai of Wu in a more positive light. Wu Kaisheng 吴闿生 mentioned that:

Only Wu who developed from a barbaric state and also the descendant of the eldest son of King Zhou, could be depended on to revive the Zhou royalty. However, he was not successful, and Zuo Qiuming was in distraught. (Wu 1131)”

独吴起于蛮夷, 为周室之长, 若可望其兴复者, 而卒蹶不振, 左氏盖尤伤之。

He pointed out that Zuo Qiuming 左丘明 paid special attention to King Fuchai's every action, hence he had great success in recreating a multifaceted image of King Fuchai.

During the Battle of Fujiao in the $14^{\text {th }}$ year of Duke Ding's reign, King Goujian of Yue employed extraordinary tactics against Wu and mortally defeated King Helu - father of King Fuchai of Wu- and this was when King Fuchai made his debut in China's history. He instructed people to remind him to avenge his father - which was similar to King Goujian's later resolve to avenge his father - demonstrating his determined and strong character. Three years later, he led a successful expedition against Yue, proving his talent in politics and military strategies. The King Fuchai of the day was 
not someone who seek ease and was easily satisfied with his success, instead, he had great ambitions and worked to attain them. Following his failure, King Goujian of Yue seek to make peace with Wu through Taizai Pi’s 太宰唯, and "the viscount of Wu was about to grant his request". King Fuchai was simply giving up something that could be his. Thereafter, he refused to heed Shenxu's advice; agreed to a peace agreement with Wu but failed to conclude it; and did not conform to lifa by not informing the other States of his successful conquest. ${ }^{3}$ His hastiness in handling these matters demonstrated his over-confidence and haughtiness in managing the entire situation. He had obviously inherited his ancestors' aspiration of ruling all the States, instead of just gaining control over Yue. Zuozhuan detailed that Wu grew stronger under the leadership of King Shoumeng 寿梦:

$\mathrm{Wu}$ then began to attack $\mathrm{Chu}$, invading $\mathrm{Chao}$ and $\mathrm{Xu}$, to the relief of which Zizhong was obliged to hurry. After the meeting at Malin, when Wu entered Zhoulai, Zizhong hurried there from Zheng. Thus it was that he and Zifan in one year flew about on seven different commissions. The tribes of the south and east which belonged to $\mathrm{Chu}$ were all taken by $\mathrm{Wu}$, which now began to have much communication with the superior States [of the north] (Yang 835; Legge 364).

吴始伐楚, 伐巢, 伐徐, 子重奔命, 马陵之会, 吴入州来, 子重自郑奔命, 子重, 子反, 于是乎一岁七奔命, 蛮夷属于楚者, 吴尽取之, 是以始大, 通吴于上国。

Since then, maintaining friendly relations with all States and being the hegemon of the Central Plains, have been the aspirations of all Kings of Wu, King Helu and King Fuchai were no exceptions. Therefore, King Fuchai of Wu turned a deaf ear on Wu Yuan's 伍员 advice as he felt that an old official like Wu Yuan did not understand his great ambitions. King Fuchai now carried away by his successful conquest, refused to follow advice suggesting he slowed down. Instead, he stubbornly pushed his way through, seeking to fulfil his and his ancestors' ambitions. With his eyes set on greater things, Yue was no longer relevant.

In his future battles - assault of Chen; invasion of Cai; war with Chu; battle against Lu; construction of Hangou; assault of Qi; rivalry with Jin - victories outnumbered defeats and for a period in history, he seemed formidable. After Zifu Jingbo's of Lu left the meeting of Huangchi, he said:

From the king down, the symbols of jade and offerings of silk at the court and complimentary visits to other States are different. Hence the contributions of our poor States to Wu are larger [now] than to Jin, embracing everything, because we consider [the lord of $\mathrm{Wu}$ ] to be the leading prince (Yang 1678; Legge 832).

自王以下，朝聘玉帛不同，故敉邑之职贡于吴，有丰于晋，无不及焉，以为伯也。

Through these calm narratives, Zuozhuan presented a King Fuchai of Wu who was targeted, bold, militarily-talented hegemon.

At the same time, it utilised views of $\mathrm{Wu}$ Zixu of $\mathrm{Wu}$, Chen Fenghua 陈逢滑 of Chen, Zixi of Chu, Zifu Jingbo and Zigong of Lu, Ziyu 子羽 of Zheng etc., to present how battlefield victories had changed King Fuchai of Wu into someone opinionated, arrogant, emulative, hot-headed, and debaucherous. Gao Shiqi 高士奇 summarised it as:

Since his victory against $\mathrm{Chu}$, he has been overwhelmed by ambitions, raging wars to expand territories - Qi and Lu - and became increasingly arrogant with every success, spending his days indulging in debauchery. (Gao 809)”

破楚以来, 雄心益肆, 称兵上国, 结畔齐鲁, 战胜攻克骄其中, 台池嫔御盅其外。

In his quest for hegemony, he refused advice from others. Therefore, it was no surprise that "he cut the throats of seven men about his tent" when he got news of Yue assaulting his homeland as he was out battling Jin. This account in Zuozhuan vividly depicted the King's anger and indignation.

King Fuchai's characterisation was further enhanced in Zuozhuan's narrative of his last moments. After Yue's conquering of $\mathrm{Wu}$, Chu Long 楚隆 paid King Fuchai of Wu a visit. The King was able to maintain the stature of a ruler, presenting his guest with a gift of pearls in appreciation of his friendship. He then bares his heart to Chu Long, "Goujian will cause me grief while I live; I would die, but death will not come." Revealing that it was never his intention to live on after the defeat. He has long decided to die a martyr's death, preserving the pride of a sovereign. In the final moment of his life, he did not indulge in self-pity or beg for assistance, instead he joked, "I would now ask you a question as with the laugh of a drowning man, how was that your historiographer An got his reputation of wisdom?" At this moment, it was admirable that he was concerned about humanity and morality instead of his survival. In his reply, Chu Long said, "when he advanced, incurred no hatred, and when he retired, was followed by no reviling." The King rejoiced in agreement, "His character was deserved." It was only behind this glamour and when the party has ended, will you return to your true self. The King Fuchai of Wu who has experienced crushing defeat was no longer conceited, but appeared sincere and humble. After its victory, King Goujian of Yue intended for King Fuchai of Wu to be relocated to Yongdong, but the latter calmly rejected the offer by saying, "I am old; how can I serve your lordship?" Following which, he ended his life and that marked the tragic ending of a hegemon. Han Xichou commended King Fuchai's actions: “A true man either succeeds in his quest for hegemony or dies trying, after [King Fuchai] only Xiang Yu 项羽 and Li Cunxu 李存勋 were worthy of being one. (Han 776)”

Zuozhuan's moving narrative was successful in recreating a King Fuchai who was courageous but had no regard for his people; confident and positive but impetuous; military talented but violent; responsible but made bad decisions; and eventually becoming a failed hero. 
In a comparison of the two texts' characterisation of King Goujian of Yue, it was noted that he was barely mentioned and almost non-existent in Zuozhuan. In fact, he was only recorded as the victor who defeated King Fuchai. Wu Kaisheng rationalised it as:

The actions of the Five Hegemons [of the Spring and Autumn period] were against the teachings of Confucius. But in Zuozhuan, Duke Huan of Qi and Duke Wen of Jin were written in positive light as the author valued their respect for the Zhou royalty. Although Duke Mu of Qin and King Zhuang of Chu were not hardworking rulers, they appointed able people to suitable positions. As for Duke Xiang of Song who did not have any outstanding achievement, he was commendable as he succeeded in defending Song from Chu's invasion. King Fuchai might be violent, but being the descendants of Zhou royalty, Zuozhuan was more reserved in its comments. But King Goujian of Yue, who was the descendant of barbarians and succeeded through conspiracies, was despised by Zuo Qiuming, who was unwilling to write more about him. While the names of Fan Li, Wenzhong, and their peers, will never make it into Zuozhuan, was a sign of Zuo Qiuming's views [on these historical matters] ( $\mathrm{Wu} 1132)$.

五霸, 圣门所不道。而《传》于桓、文颇张之者, 重其尊周室也。秦穆、楚庄虽不勤王, 而能用贤，亦皆令主。宋襄虽无成功，而志在攘楚，故亦可嘉。夫差凶暴，而周室之裔， 故《传》亦矜之。至越勾践, 起于夷狄, 而专以阴谋取胜, 乃左氏所不屑道, 故从无一特 赦之笔。范蟲、文种辈, 其姓名绝不加载《传》中, 可见左公用意处也。

In Zuozhuan's narrative, Wu's success was built on conspiracies and sneak attacks on Wu, hence King Goujian of Yue was seen in a negative light.

On the other hand, King Goujian being the protagonist in Wuyu and Yueyu, was portrayed as the wise ruler who endured humiliation to attain his goal; courteous to the wise; put able people in suitable posts; and willing to accept advice. This was in sharp contrast with the over-ambitious, opinionated, stubborn, and reckless King Fuchai.

\section{Conclusion}

The sections of Wиуи and Yиеуи in Guоyu, and Zuоzhuan contained narratives of the Wu-Yue rivalry, but presented in different narrative styles - the former compiled anecdotes in a locale-based narrative style, while the latter recorded historical events in chronological narrative style. Wиуи and Yиеуu only had contents on the Wu-Yue rivalry, focusing on King Goujian's conquest of Wu. It developed the plot and characters through dialogues between historical figures. On the other hand, Zuozhuan chronicled historical events in a chronological manner, scattering disjointed information in its narration that when put together would form a coherent plot. Words spoken by the characters in Zuozhuan also applied a finishing touch, enhancing the fullness of the plot.

Zuozhuan, being in the chronological narrative format, has plot scattered in different events and characters, resulting in an incoherent narration of a plot. In contrast, Guoyu organises its narration by state and region, hence it was able to keep its focus on the $\mathrm{Wu}-Y u e$ rivalry. But this arrangement has its drawbacks in which remote causes could not be included in the limited timeframe.

Both texts chronicled the $\mathrm{Wu}$-Yue rivalry in different narrative styles, either in chronologically or locale-based, creating different plot development, plot focus, and characterisation. Revealing the authors' distinct narrative perspective and purpose. Zuozhuan stresses on the need to honour the king and drive off the barbarians 尊王攘夷, and to respect the order of $l i$. Affirming men's positive role in creating history and maintaining the social order. While Guoyu stresses the need to "learn from past mistakes to prevent incurring the same ones", emphasising the importance of wise rulers, honourable officials, and acceptance of advice. This was pointed out in the ending of Wuyu: "The dying King Fuchai of $\mathrm{Wu}$ asked this message to be passed to Zixu, "If the dead have no consciousness, so be it; if the dead do have consciousness, then how am I going to face the loyal official Wuyuan!' And he killed himself." This was to echo the words of Wu Zixu when killed himself for his advice was not heeded, "Cut off my head and hang it over the capital's East Gate, I want to witness Yue's invasion and the collapse of Wu with my own eyes." Following this, the author did a narrative intervention to clarify his stand and opinions by relating, "After wiping out the State of Wu, King Goujian of Yue pushed his troops northward to attack the other states. The rulers of these states knew they were no match and hence, the States of Song, Zheng, Lu, Wei, Chen, Cai etc., brought their symbols of jade and submitted to the rule of King Goujian. King Goujian of Yue was able to succeed as he treated his officials with respect and was willing to listen and accept their ideas."

\section{References}

Gao, S. Q. (1979). Zuozhuan jishibenmo 左传纪事本末. Beijing: Zhonghua shuju. Print.

Genette, G. (1990). Xushi huayuxin xushi huayu 叙事话语•新叙事话语. Trans. Wang Wenrong 王文融. Beijing: China Social Science Press. Print.

Han, X. C. 韩席筹. (1975). Zuozhuan fenguo jizhu 左传分国集注. Taipei: Huashi chubanshe. Print.

Lee, L. S. 李隆献. “Xushillilun yu shijian: yi Zuozhuan wei duixiang xulun” 叙事理论与实践一以《左传》为对象・叙论. National Taiwan University Department of Chinese Literature. 12 April 2008. 
Legge, J. (1872). The Chinese Classics Vol.5. Hong Kong: Lane, Crawford \& Co. Print.

Rimmon-Kenan, S. (1989). Xushi xugou zuopin叙事虚构作品. Trans. Yao Jinqing 姚锦清 et al. Shanghai: Sanlian shudian. Print.

Ruan, Y. 阮元校. (1980). Shisanjing zhushu (fu jiaokanji) Vol. 1\&2 十三经注疏（附校勘记）. Beijing: Zhonghua shuju. Print.

White, H. (2003). Houxiandai lishi xushixue 后现代历史叙事学. Trans. Chen Yonguo 陈永国. Beijing: China Social Science Press. Print.

Wu, K. S. 吴㬝生. (1995). Zuozhuan wei 左传微. Hefei: Huangshan shushe. Print.

Xu, Y. G. 徐元诰. (2002). Guoyu jijie 国语集解. Beijing: Zhonghua shuju. Print.

Li, J.李佳. (2015). Stuy of Guoyu国语研究. Beijing: China Social Science Press. Print.

Yang, B. J. 杨伯峻. (1990). Chunqiu Zuozhuan zhu Vol. 4 春秋左传注第四册. Beijing: Zhonghua shuju. Print.

\section{Notes}

1. This paper records calendar years using the posthumous titles of the Dukes of Lu. Henceforth, "Lu" will be omitted in the presentation of years.

2. Translations for Chunqiu Zuozhuan zhu are taken from James Legge's The Chinese Classics with minor editing and names changed to pinyin romanisation; the same applies to all subsequent translations of Chunqiu Zuozhuan zhu.

3. It was recorded in “Wengong shisinian 文公十四年” of Zuozhuan that, “On the death of Duke Wen of Chu, the duke sent his condolences by an officer, who did not behave respectfully; and a body of troops from Chu came to punish [the slight], and invaded our southern border. 凡崩、薨, 不赴, 则不书。祸、福, 不告, 亦不书。惩不敬也”. From Chunqiu Zuozhuan zhu Vol.2, p.602. 